\section{新 $\alpha^{\prime}$ マルテンサイト型 $\mathrm{Ti}$ 合金の組織制御と 高機能化に関する紹介を中心として}

松 本 洋 明*

\section{1. は じめに}

今回，本稿を執筆する機会を与えていただき，関係各位に 深く感謝申し上げる．私は大学院を修了後に金属関係の企業 に勤め, その後に東北大学金属材料研究所に戻り, 花田修治 名誉教授のもと生体用チタン合金の研究に携わり，金属材料 研究について様々な面からご指導頂いた．2006年11月から 同研究所加工プロセ久工学研究部門の千葉晶彦教授のもと耐 熱材料, 生体用金属材料抢よび構造用金属材料の各種塑性加 エプロセスを駆使した組織制御技術と高機能化技術について 基礎打よび応用の両面から厚くご指導頂きながら, 研究を遂 行している.本稿では，これまでに私が取り組んできた新し いタイプの構造用 $\alpha^{\prime}$ 型 $\mathrm{Ti}$ 合金と $\alpha^{\prime}$ を利用した新しい加工技 術の開発に関する研究を中心に報告するとともに，現在所属 する研究室で精力的に取り組んでいる耐熱 $\mathrm{Co}$ 基合金抢よび 生体用 $\mathrm{Co}$ 基合金に関する研究についても紹介する。 また紙 数の都合上, 詳細は参考文献を参照頂ければ幸いである.

2. 新しいタイプの構造用 $\alpha^{\prime}$ マルテンサイト型 $\mathrm{Ti}$ 合 金の合金設計と $\alpha^{\prime}$ 相を利用した新しい組織制御・ 加工技術( $\alpha^{\prime}$ プロセッシング)の可能性

$\mathrm{CO}_{2}$ 排出削減などの環境問題から近年, 航空機や自動車 などの輸送機器の軽量化が重要視され, 軽量金属材料である $\mathrm{Ti}$ 合金の需要が急速に伸びている. 我々は構造用 $\mathrm{T} i$ 合金と しては未開拓の $\alpha^{\prime}$ マルテンサイトを主相とした $\mathrm{Ti}-\mathrm{V}$ 系合金 に注目して, 世界最高レベルな低ヤング率 $(47 \mathrm{GPa})$-高強度 特性 (1100 MPa) を実現させた ${ }^{(1)}$ 。この合金設計技術につい ては，他の Ti 合金系にも展開可能である。また， $\alpha^{\prime}$ 相の特 性 (良好な加工特性, 微細な組織形成(焼入れ後で幅 $1 \mu \mathrm{m}$ 程
度の微細なアシキュラー状の組織を示し, わずかな加工量で 冷間加工を行うことで $200 \mathrm{~nm}$ 以下の微細な等軸状結晶粒組 織), 焼入れ後でランダムな結晶配向)を活かした産業用 $\mathrm{Ti}$ 合金の新しい組織制御技術・高機能化技術 ( $\alpha^{\prime}$ プロセッシン グ)の可能性について現在, 研究を遂行しているところであ る. 本稿ではこの $\alpha^{\prime}$ 相を主相とした Ti 合金の特徵と $\alpha^{\prime}$ 相を 利用した $\alpha^{\prime}$ プロセッシングの可能性について紹介する.

（1）低ヤング率-高強度 新 $\alpha^{\prime}$ マルテンサイト型 Ti-V 系 合金の合金設計

図 1 は $1223 \mathrm{~K}$ もくは $1323 \mathrm{~K}$ で水水中に溶体化焼入れ 処理をした Ti-V-Sn 系合金のヤング率を Ti-V-Sn 3 元系状 態図上に表記した図を示している。ここで $\alpha^{\prime}$ 相(H.C.P.)の 組成打よび準安定 $\beta$ (B.C.C.) の組成にて低いヤング率 (50〜 $70 \mathrm{GPa})$ を示すことが分かる. 特に $\alpha^{\prime}$ の組成では $\alpha^{\prime} / \beta+$ $\left(\alpha^{\prime}+\alpha^{\prime \prime}\right)$ の相境界付近, $\beta$ の組成では $\alpha^{\prime} や \alpha^{\prime \prime}$ (Orthorhombic)のマルテンサイト相が生成しない相境界付近で低いヤン グ率を示す。準安定 $\beta$ の組成で低いヤング率を示す報告は 多くあり(2)(3), 焼入れ過程の Athermal $\omega$ 変態を抑制して, 更にマルテンサイト変態 $\left(\beta / \alpha^{\prime \prime}\right)$ に対して $\beta$ 相が最も不安定 な組成にて主にラティスソフトニングに起因してヤング率は 最小を示すことが分かっている(2)．この $\beta$ 型Ti合金は良好 な冷間加工特性を示すことから, 輸送機器用サスペンション ばねやスポーツ用品に応用される。また，この低ヤング率な 構造用 $\mathrm{Ti}$ 合金の多くは $\beta$ 型 $\mathrm{Ti}$ 合金が使用され, ヤング率 に関する研究も $\beta$ 型 Ti 合金での報告がほとんどである。一 方, 上記した通り, $\mathrm{Ti}-\mathrm{V}$ 系合金では $\alpha^{\prime}$ 相を主相とする組成 にて $\beta$ 型 Ti 合金と同様な低ヤング率特性を示す．更に Sn 添加により $\alpha^{\prime}$ 相抢よび $\beta$ 相ともに $60 \mathrm{GPa}$ 以下の低ヤング率 化が可能となり(2), Al 添加でも同様な結果が得られている.

次に $\alpha^{\prime}$ 型 Ti 合金の低ヤング率化機構について考えてみた

* 東北大学助教 ; 金属材料研究所加工プロセス工学研究部門 ( $9980-8577$ 仙台市青葉区片平 2-1-1)

Introduction of Microstructural Control and High Functionalizing of the New $\alpha^{\prime}$ Martensite Ti Alloys; Hiroaki Matsumoto(Institute for Materials Research, Tohoku University, Sendai)

Keywords: titanium alloy, thermo-mechanical processing, heat resistant material, biomedical material, cobalt based alloy 2009年 3 月 24 日受理 


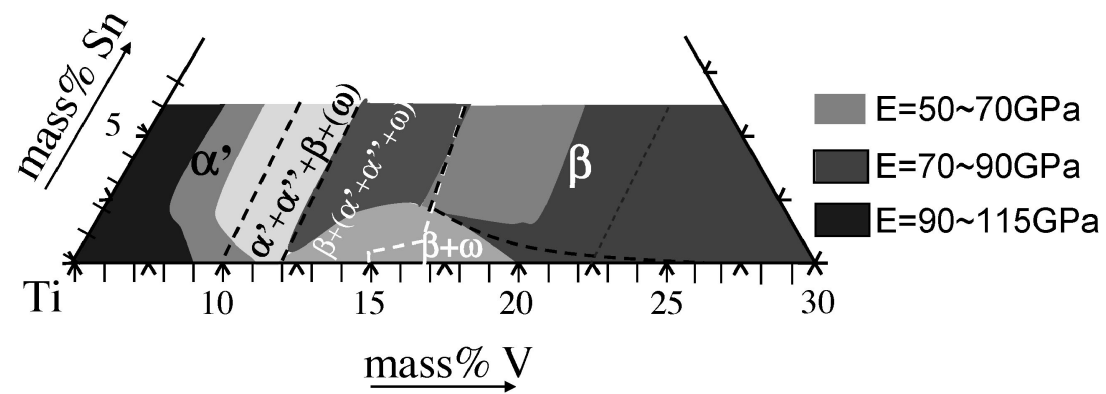

図 $11223 \mathrm{~K}$ あるいは $1323 \mathrm{~K}$ で溶体化焼入れ処理した Ti-V-Sn 合金の相構成とヤング率 $(\mathrm{E})$ の関係.

い.これまで $\mathrm{Ti}$ 合金のヤング率を構成相で比較した場合, ヤング率は $\omega$ 相(H.C.P.)で最も高く, 次に $\alpha$ 相 (H.C.P.), $\beta$ 相 (B.C.C.) の順に低くなることが報告されている(4). Bowen はこの構成相とヤング率の関係について $\omega$ 相のヤン グ率は $\beta$ 相の 2 倍, $\alpha$ 相のヤング率は $\beta$ 相の 1.5 倍であるこ とを具体的に指摘している ${ }^{(5)}$. 一方, $\alpha^{\prime}$ 相や $\alpha^{\prime \prime}$ 相のマルテ ンサイト相のヤング率に関する報告に関して, マルテンサイ 卜相の生成でヤング率は変化することが指摘されている が(6), 詳細な報告はない。 $\alpha^{\prime}$ 相の時効熱処理過程では Isothermal $\omega$ 変態はなく, 熱処理温度に依存して $\alpha^{\prime}$ 相は $\left(\alpha^{\prime}+\beta\right)$ もしくは $(\alpha+\beta)$ に相分解し，それに伴いヤング率は $60 \mathrm{GPa}$ 程度から $100 \mathrm{GPa}$ 近くまでに増加する。この結果は 構成相として $\alpha^{\prime}$ 相が最も低いヤング率を示すことを意味す るが， $\alpha^{\prime}$ 相は H.C.P. 構造であり，Ti 合金のヤング率は本質 的に結晶構造に依存した值なのか，もしくはマルテンサイト 相特有の格子不安定性に強く影響されたのか疑問が残る.

H.C.P. 相の格子定数に注目すると, 溶体化焼入れ後の ( Ti$12 \mathrm{~V})-2 \mathrm{Al}$ 合金 $(\operatorname{mass} \%) の \alpha^{\prime}$ 相の格子定数は $\mathrm{a}=0.294 \mathrm{~nm}$, $\mathrm{c}=0.463 \mathrm{~nm}$ であり, $673 \mathrm{~K}-86.4 \mathrm{ks}$ の熱処理後の $\alpha^{\prime}$ 相の格 子定数は $\mathrm{a}=0.294 \mathrm{~nm}, \mathrm{c}=0.467 \mathrm{~nm}$ で, わずかに $\mathrm{c}$ 軸が膨 張する.この熱処理過程で, ヤング率は $63 \mathrm{GPa}$ から 90 $\mathrm{GPa}$ 近くまでに増加する. $673 \mathrm{~K}$ の熱処理では, 構成相は $\alpha^{\prime}$ 単相のままで, 一方で上記した通り格子は膨張することか ら, 合金組成や格子体積との関係から上記したヤング率の変 化を説明することはできない， Ti 合金の準安定 $\beta$ 相のヤン グ率はマルテンサイト変態に対する格子安定性でよく議論さ れ ${ }^{(7)}$, 非線形的な弾性変形挙動 ${ }^{(8)}, c_{11}-c_{12}$ の特定方位の弾性 定数が異常に小さくなる弾性異常現象 ${ }^{(9)}$, 更に応力誘起マル テンサイト変態とマルテンサイトバリアントの再配列過 程(10)などが低ヤング率化機構として挙げられている．その ため, 準安定 $\beta$ 型 $\mathrm{Ti}$ 合金では室温で最も格子不安定な組成 にてヤング率は最小を示す。一方でこれは $\beta$ 相が非常に不 安定な組成に限られ，低ヤング率な $\alpha^{\prime}$ 型 $\mathrm{Ti}$ 合金，例えば $\alpha^{\prime}$ 型 $(\mathrm{Ti}-12 \mathrm{~V})-2 \mathrm{Al}$ 合金のマルテンサイト逆変態 $\left(\alpha^{\prime} / \beta\right)$ 温 度は $673 \mathrm{~K}$ 以上であり, 不安定な準安定 $\beta$ 型 $\mathrm{Ti}$ 合金に比べ て室温で $\alpha^{\prime}$ 相は安定である. そのため $\alpha^{\prime}$ 型 $\mathrm{Ti}$ 合金が準安定 $\beta$ 型 Ti 合金と比較して室温で同等以下の低ヤング率を示す 理由について同じようなマルテンサイト相の格子不安定性で 説明することができない。溶体化焼入れ後の $\alpha^{\prime}$ 型 $\mathrm{Ti}$ 合金の 室温での引張試験の応力ーひずみ曲線では, 不安定な準安定 $\beta$ 型Ti合金と同様に弾性变形過程で擬弾性挙動が観察され
る. マルテンサイト相の擬弾性変形は主に双晶界面やマルテ ンサイトバリアント界面の移動に強く影響を受ける(11)。こ の擬弾性挙動は見掛けのヤング率を減少させるために， $\alpha^{\prime}$ 型 $\mathrm{Ti}$ 合金の低ヤング率化機構の要因として挙げることができ る.しかしながら， $\alpha^{\prime}$ 型 Ti 合金の冷間加工材では溶体化焼 入れ材で観察された擬弾性変形挙動は明瞭に現れず, 一方 で, 加工後のヤング率は溶体化焼入れ後に比べて更に減少す

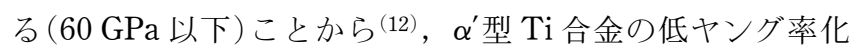
機構が擬弾性変形挙動に強く影響を受けることを断定するこ とはできない。また，上記した通り，他の相と比較した際， $\alpha^{\prime}$ 相のヤング率を結晶構造の違いで説明することはできな い. そのため, $\alpha^{\prime}$ 型 $\mathrm{Ti}$ 合金の低ヤング率化機構は不明な点 が多く, 更に詳細な解析が必要であるのが現状である. 一方 で, 工業的な点から考慮すると, $\alpha^{\prime}$ 型 $\mathrm{Ti}$ 合金は $\beta$ 型 $\mathrm{Ti}$ 合 金に比べて高価な $\beta$ 安定化元素量が低減でき, また合金種 および組成にも依存するが，同等な冷間加工性を示すことか ら新しいタイプの低ヤング率 $\mathrm{Ti}$ 合金として期待できる.

\section{（2） $\alpha^{\prime}$ 相を利用した構造用 Ti 合金の高機能化プロセス}

ここでは $\alpha^{\prime}$ 型 Ti 合金の冷間加工制御した低ヤング率一高 強度化プロセスと $\alpha^{\prime}$ 相を利用した新しい組織制御・高機能 化技術である $\alpha^{\prime}$ プロセッシングの可能性について報告す る. 図 2 は溶体化焼入れ後に減面率 $75 \%$ で冷間溝ロール加 工した $\alpha^{\prime}$ 型 $(\mathrm{Ti}-12 \mathrm{~V})-2 \mathrm{Al}$ 合金の透過型電子顕微鏡 $(\mathrm{TEM})$ 像 ( (a) 明視野像, (b) 制限視野電子回折図形, (c) 暗視野像) および $(\mathrm{d})$ 高分解能電子顕微鏡 (HREM) 像を示している. TEM 像から冷間加工後に針状の $\alpha^{\prime}$ マルテンサイト組織は, ランダムな結晶配向から成る数十 $\mathrm{nm}$ の微細な等軸状転位セ ル組織に変化していることがわかる. HREM 像(図 2(d)) は $\alpha^{\prime}$ 粒内を撮影して抢り，多数のモアレ縞が観察される. HREM 像中には電子線制限視野回折図形も示しており, こ れは Orthorhombic の $\alpha^{\prime \prime}$ に相当する回折図形も観察され, 冷間加工過程で数 $\mathrm{nm}$ オーダーの超微細な $\alpha$ ”相が生成して いることがわかる．この $\alpha^{\prime \prime}$ 相の生成量に関しては, XRD プ

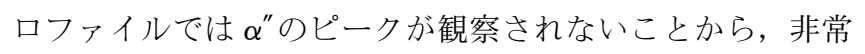
に微量であることが推察される. 一方で生成サイトや生成過 程は現在, 不明であり, 今後解明する必要がある. 以前に $\alpha^{\prime}$ 相の塑性変形過程は変形量の増加とともに〈a+c〉すべりが 活発に活動して, これが高い冷間圧延性を示す要因として指 摘した ${ }^{(13)}$. 冷間加工中の $\alpha^{\prime \prime}$ 相の生成過程は現在, 不明であ るが，加工過程の $\alpha$ "相生成も高い冷間圧延性を示す要因と 

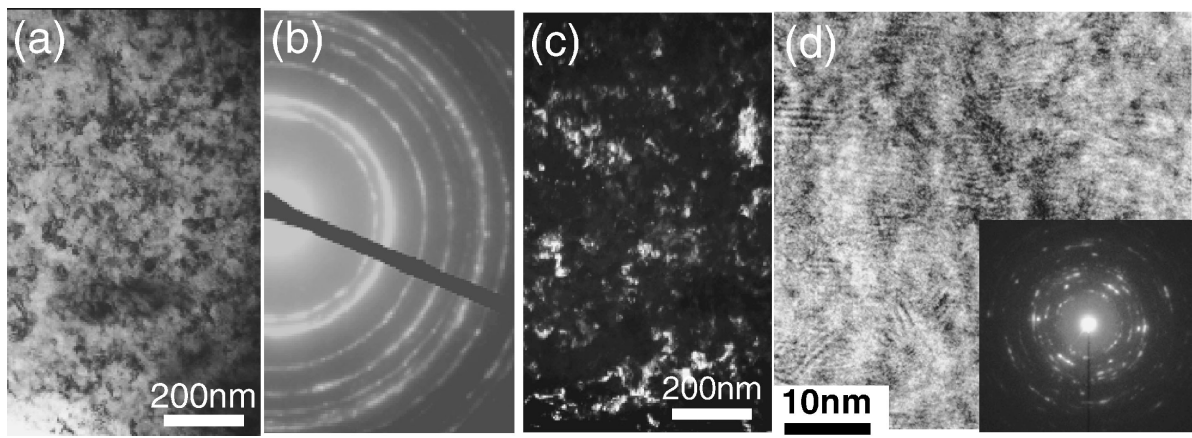

図 $2 \quad \alpha^{\prime}$ 型 $(\mathrm{Ti}-12 \mathrm{~V})-2 \mathrm{Al}$ 合金の冷間加工後の透過型電子顕微鏡 $(\mathrm{TEM})$ 像.（(a) 明視野像，（b)制限視野電子回折図 形，（c)暗視野像) 抢よび (d) 高分解電子顕微鏡 $(\mathrm{HREM})$ 像.

表 $1 \alpha^{\prime}$ 型 $\mathrm{Ti}$ 合金および構造用 $\mathrm{Ti}$ 合金の機械的性質.

\begin{tabular}{|c|c|c|c|c|c|}
\hline Alloy & $\mathrm{E}(\mathrm{GPa})$ & $\mathrm{YS}(\mathrm{MPa})$ & UTS (MPa) & $\mathrm{EL}(\%)$ & Condition \\
\hline \multicolumn{6}{|l|}{$\alpha$ type } \\
\hline High purity Ti & $100 \sim 145$ & 140 & 235 & 50 & \\
\hline \multicolumn{6}{|l|}{$(\alpha+\beta)$ type } \\
\hline Ti-6Al-4V & $110 \sim 140$ & $800 \sim 1100$ & $900 \sim 1200$ & $13 \sim 16$ & \\
\hline \multicolumn{6}{|l|}{ Metastable $\beta$ type } \\
\hline $\mathrm{Ti}-10 \mathrm{~V}-2 \mathrm{Fe}-3 \mathrm{Al}$ & 110 & $1000 \sim 1200$ & $1000 \sim 1400$ & $6 \sim 16$ & \\
\hline Ti-15V-3Cr-3Al-3Sn & $80 \sim 100$ & $800 \sim 1000$ & $800 \sim 1100$ & $10 \sim 20$ & \\
\hline \multicolumn{6}{|l|}{$\alpha^{\prime}$-type in this work } \\
\hline$(\mathrm{Ti}-8 \mathrm{~V})-4 \mathrm{Sn}$ & 57.3 & 872 & 954 & 8.5 & CGR \\
\hline$(\mathrm{Ti}-12 \mathrm{~V})-6 \mathrm{Sn}$ & 47.5 & 865 & 1028 & 9.4 & CGR \\
\hline$(\mathrm{Ti}-12 \mathrm{~V})-2 \mathrm{Al}$ & 53.3 & 945 & 1047 & 3 & CGR \\
\hline $\begin{array}{l}\text { Metastable } \beta \text {-type } \\
\quad(\mathrm{Ti}-20 \mathrm{~V})-4 \mathrm{Sn}\end{array}$ & 61.7 & 693 & 796 & 13 & CGR \\
\hline
\end{tabular}

CGR : Cold groove bar deformed at diameter from $10 \mathrm{~mm}$ to $5 \mathrm{~mm}$, E : Young's modulus, YS : Yield stress, UTS : Ultimate tensile stress and EL : Elongation to fracture.

して挙げることができる. なた冷間溝ロール加工後に 573 K-21.6 ks で熱処理した組織は微細な等軸状組織のますで加 工により生成した $\alpha^{\prime \prime}$ 相は $573 \mathrm{~K}$ の熱処理で $\alpha^{\prime}$ 相に逆変態す る. 冷間溝ロール加工後に $\alpha^{\prime}$ 相は棒材の長手方向に強い $\langle 10 \overline{1} 0\rangle$ 繊維集合組織が形成されるが(1)，573 K での低温の 長時間保持熱処理後においても強い〈10 $\overline{1} 0\rangle$ 繊維集合組織は 維持されており，またXRD や組織観察から $\beta$ 相の生成は確 認されないことから, 強い相分解は起きないことが分かって いる. 一方で, この $573 \mathrm{~K}$ の熱処理過程でヤング率および 強度は著しく増加する. 表 $1^{(14)}$ は各 $\alpha^{\prime}$ 型 $\mathrm{Ti}$ 合金の冷間溝口 一ル加工後(減面率 : 75\%)の棒材の長手方向のヤング率お よび引張特性について純 $\mathrm{Ti}$ 抢よび他の構造用 $\mathrm{Ti}-\mathrm{V}$ 系合金 の特性と併せて示している。これらの $\alpha^{\prime}$ 型 Ti 合金の溶体化 焼入れ後のヤング率は $60 \sim 80 \mathrm{GPa}$ であり, 冷間溝ロール加 工後でヤング率は $60 \mathrm{GPa}$ 以下まで減少して， $\alpha^{\prime}$ 型 $(\mathrm{Ti}-$ $12 \mathrm{~V})-6 \mathrm{Sn}$ 合金で $47.5 \mathrm{GPa}$ の最小值を示すことがわかる. 更に溶体化焼入れ後の強度は $690 \sim 760 \mathrm{MPa}$ であり，冷間 溝ロール加工後に $200 \mathrm{MPa}$ 以上強度が増加している. 一般 に H.C.P. 金属でヤング率の異方性は (0001)の底面内方位で 最小を示し， c 軸方位で最大を示す ${ }^{(15)}$ 。 $\alpha^{\prime}$ 型 Ti 合金のヤン グ率の異方性も H.C.P.の結晶方位との関係で整理でき ${ }^{(13)}$, 冷間溝ロール加工後のヤング率の著しい減少は強い〈10 10$\rangle$
繊維集合組織形成によるためと考えられる。このように $\alpha^{\prime}$ 型 Ti 合金にて冷間加工は高強度化だけでなく，低ヤング率 化にも有効なプロセスであることがわかる．更に， $\alpha^{\prime}$ 型 $\mathrm{T} i$ 合金は簡便なクロス圧延法による加工制御でランダムな結晶 配向を示し，それに伴い板材の機械的特性の面内異方性は低 減される(16). 溶体化焼入れした板材においても， $\alpha^{\prime}$ 相はラ ンダムな結晶配向を示し，ヤング率および機械的特性の面内 異方性はほとんど観察されない(13)。これまで Ti 合金の $\alpha^{\prime}$ および $\alpha^{\prime \prime}$ のマルテンサイト相は，鉄鋼材料のマルテンサイ トとは異なり, 高強度化に寄与しない観点から構造用として 全く利用されていないのが現状である。一方で，これらの結 果は $\alpha^{\prime}$ 相を介した加工一熱処理によりヤング率, 強度特性, 室温延性，更には集合組織の広範囲な制御が可能であること

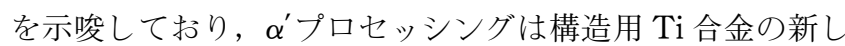
い高機能化・加工プロセスの可能性を示している.

\section{3. 新しい高温強化機構を有する耐熱 $\mathrm{Co}-\mathrm{Ni}$ 基合金 に関する研究}

航空機・発電用ガスタービンのエネルギー変換効率の向上 のためにガスタービン使用温度の向上を目指した材料開発は この30年来，世界的に活発に研究されてきた。その主役は 


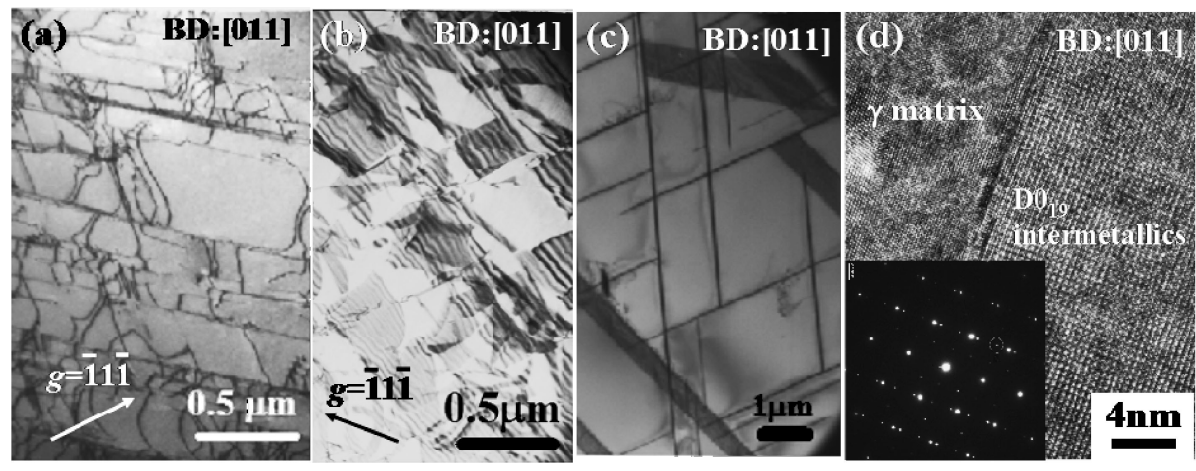

図 $3 \mathrm{Co}-\mathrm{Ni}$ 基合金の（a）10\%引張変形後，同変形後（b） $973 \mathrm{~K}-36 \mathrm{ks}$ および (c) $1073 \mathrm{~K}-1814.4 \mathrm{ks}$ の熱処理後の TEM 像ならびに(d) (c)の HREM 像.

$\mathrm{Ni}$ 基超合金であり，耐熱強化機構は $\mathrm{L} 1_{2}$ 構造の金属間化合 物 $\mathrm{Ni}_{3} \mathrm{Al}\left(\gamma^{\prime}\right)$ の析出強化を基本としている. 最近では, $\mathrm{Co}$ 基 合金に抢いても $\gamma^{\prime}$ 相の生成が確認され，新しい耐熱合金と して注目を浴びている(17)-(19)。一方，この $\gamma^{\prime}$ 相を含んだ合 金は塑性加工性に乏しいという問題がある。千葉らはこれま でに $\gamma^{\prime}$ 相強化に依らない新しい強化機構(転位強化)で耐熱 強化させるタービンディスク用 $\mathrm{Co}-\mathrm{Ni}$ 基合金 $(\mathrm{Co}-31 \mathrm{Ni}-$ $20 \mathrm{Cr}-10 \mathrm{Mo}$ ) を提案している(20)(21). 本合金の特徵は熱処理 後の炉冷状態でも高温安定相である $\gamma$ 相 (F.C.C.)が室温で安 定に保持され塑性加工性に優れること，更に $973 \sim 1073 \mathrm{~K}$ で異常強化されることが挙げられる。図 3 は(a) $\gamma$ 単相を呈 する $\mathrm{Co}-\mathrm{Ni}$ 基合金に対して室温で $10 \%$ の引張ひず反を導入 した場合にお梳る TEM 観察から得られた明視野像，(b) 同 加工後 973-36 ks で熱処理した場合の同像を示している. 図 3 (a) では, 多数の単位転位 (Burgers vector: $\langle 110\rangle$ )が観察さ れ，973 K の熱処理では転位は回復せずに広く拡張した積層 欠陥を形成しており，溶質元素が拡張転位の積層欠陥に偏析 (鈴木効果)したことを示唆している.最近では，本合金に微 量添加されている $\mathrm{Nb}$ や Co と原子量が近い Ni が熱処理過 程で優先的に積層欠陥面に偏析することを指摘してい る(22)。また図 3 (c) は図 3 (a) の状態から，さらに $1073 \mathrm{~K}-$ $1814.4 \mathrm{ks}$ 熱処理後の TEM 観察結果を示しているが, (111) $\gamma$ 上に板状の析出相が生成していることが確認でき る.これは $(\mathrm{Ni}, \mathrm{Nb})-$ rich な $\mathrm{D} 0_{19}$ 型の $\delta$ 化合物相であり ${ }^{(22)}$,

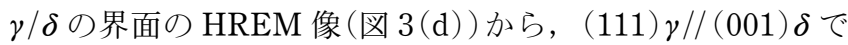
$[11 \overline{2}] \gamma / /[100] \delta$ の関係を示していることから，極めて高い 整合性を有していることがわかる. Thermo-calc を利用し た状態図計算では $1073 \mathrm{~K}$ の熱処理で Mo-rich な $\mu$ 相が優先 的に生成することが予測されたが，これは旧 $\gamma$ 粒界上に優先 的に不連続析出しており，粒内での生成はほとんぞ確認され ていない。これらの結果は, 熱処理過程で溶質元素が偏析し た (111) $\gamma$ 上の積層欠陥を核形成サイトとして $\delta$ 相が生成し たことを示唆している. 図 4 は $973 \mathrm{~K} て ゙$ 熱処理した際の保 持時間と各試験温度での圧縮試験後の $0.2 \%$ 耐力の関係を示 している.これより，熱処理過程の積層欠陥生成とその後の $\delta$ 相の生成に伴い強度は著しく増加することが確認できる. これは $\gamma^{\prime}$ 相に依らない新しい高温強化機構の可能性を示し ており, 現在, 優れた塑性加工性を兼坟備えた新しい耐熱材

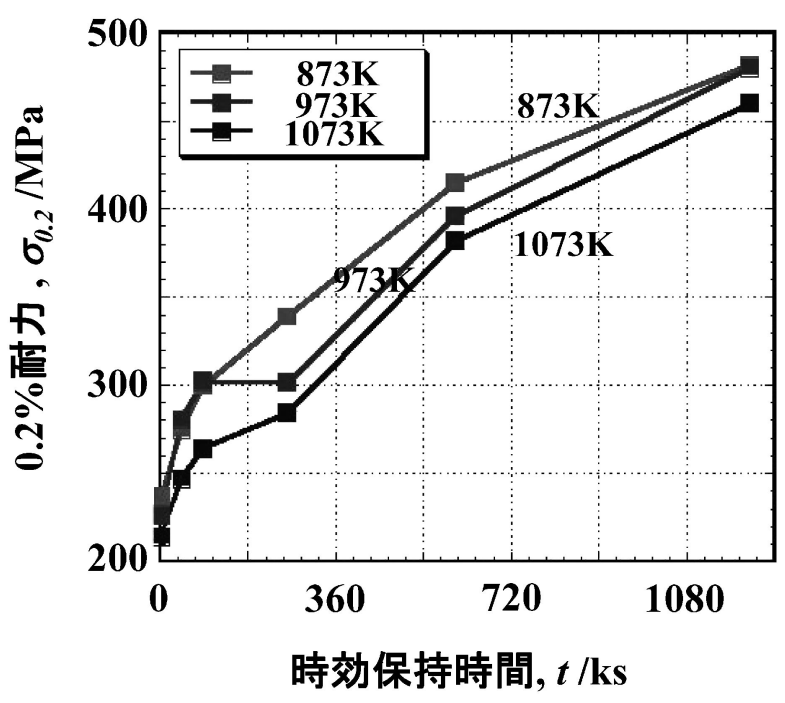

図 4 Co- $\mathrm{Ni}$ 基合金の $973 \mathrm{~K}$ 時効熱処理後の各試験温 度における $0.2 \%$ 耐力の変化.

料の合金設計と加工プロセス技術の開発を行っているところ である。

\section{4. 熱加エプロセス制御による生体用 Co-Cr-Mo 合 金の組織制御之高機能化}

近づく高齢化社会において高度先進医療技術の発展は必要 不可欠であり，それを支える金属系生体材料の高機能化は重 要な研究開発テーマの一つである。これまでに千葉らは生体 用硬組織代替用金属材料として生体に無害な $\mathrm{Ni}$ フリー $\mathrm{Co}-$ $\mathrm{Cr}-\mathrm{Mo}$ 合金を提案している ${ }^{(23)}$ 。この $\mathrm{Ni}$ フリー $\mathrm{Co}-\mathrm{Cr}-\mathrm{Mo}$ 合金は，他の金属系生体材料に比べて塑性加工性能に劣るた め鋳造法で製造されるのが一般である。しかしながら，これ までの研究から不純物元素と思われがちな窒素 $(\mathrm{N})$ を適切に 合金制御することで室温延性が著しく改善されることがわか った ${ }^{(24)}$ 。これは $\mathrm{Co}-\mathrm{Cr}-\mathrm{Mo}$ 合金中で $\mathrm{N}$ 添加により $\gamma$ (F.C.C.) 相の安定度が増加し，それに伴い変形中のひずみ 誘起マルテンサイト相変態 $(\gamma / \varepsilon)$ が抑制されたためと考えら れる.

更にこの生体用 $\mathrm{Co}-\mathrm{Cr}-\mathrm{Mo}$ 合金は熱間加工温度域(1223 K 


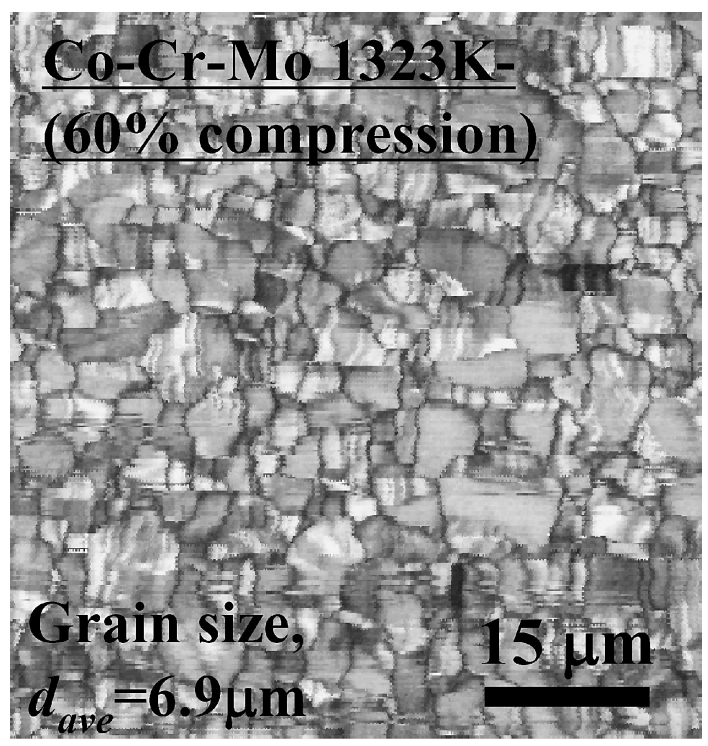

図 $51323 \mathrm{~K}$ で熱間加工した $\mathrm{Co}-29 \mathrm{Cr}-6 \mathrm{Mo}$ 合金の OIM-EBSD から得られたミクロ組織.

〜 $1473 \mathrm{~K})$ でも $\gamma$ 相の積層欠陥エネルギーが極めて低く， $50 \%$ 以下のひずみ量の熱間加工でも不連続型動的再結晶に よりナノオーダーまでに組織が微細化されることがわかった (図 5).これは従来の不連続動的再結晶の bulging 機構だけ でなく，変形中のせん断帯形成 (GN 転位形成) とそれを核生 成サイトとした新粒形成が加速的に進行したために低ひずみ 量でも超微細組織が形成されたと考えられる(25).この微細 組織形成は素材の高強度化に有効であり，現在，生体用 $\mathrm{Co}^{-}$ $\mathrm{Cr}-\mathrm{Mo}$ 合金のこの微細組織形成と高機能化を実現する熱間 加工条件の最適化についてエネルギー分散効率 $(\eta)$ および塑 性不安定因子 $(\xi)$ で表記されるプロセッシングマップ法 ${ }^{(26)}$ 利用しながら，行っているところである.

\section{5.おわりに}

本稿ではこれまで私が取り組んできた Ti 合金に関する研 究について報告させて頂くとともに，現在，所属する東北大 学金属材料研究所加工プロセス工学研究部門で精力的に取り 組んでいる耐熱用 Co 基材料，生体用 Co 基材料およびそれ らの加工技術の開発について紹介した．また．これらの金属 素材はそれぞれ新しい基礎現象およびコンセプトを基に現 在, 積極的に研究開発が行われており，今回紹介した幾つか の研究テーマから多少なりとも産業応用に貢献できれば幸い である。

本稿に記した研究の一部は, Ti 合金に関しては NEDO 産 業技術研究助成事業 若手研究グラント インターナショナル 分野の, 更に Co 基合金に関しては文部科学省 都市エリア 産学官連携促進事業(発展型)の支援を受けて行われているも のであり，ここに深く謝意を表する．また記した研究の多く は東北大学金属材料研究所加工プロセス工学研究部門に所属

する学生のご協力により遂行されており，ここに深く謝意を 表する.

\section{文献}

（1）松本洋明, 小平和生, 千葉晶彦：日本金属学会誌， $72(2008)$, 989-996.

( 2 ) H. Matsumoto, S. Watanabe, N. Masahashi and S. Hanada: Metall. Mater. Trans. A, 37 (2006), 3239-3249.

( 3 ) H. Y. Kim, T. Sasaki, K. Okutsu, J. I. Kim, T. Inamura, H. Hosoda and S. Miyazaki: Acta Materialia, 54(2006), 423-433.

(4) Z. Fan: Scripta Metall. Mater., 29(1993), 1427-1432.

( 5 ) A. W. Bowen: Proceedings of the Fourth International Conference on Titanium "TITANIUM'80", (1980), 1317-1326.

(6) Y. T. Lee and G. Welsh: Mater. Sci. Eng., A128 (1990), 77-89.

( 7 ) R. Boyer, G. Welsch and E. W. Collings (Eds.): Materials Properties Handbook, Titanium Alloys, (1994), 7, 94-100.

( 8 ) N. Sakaguchi, M. Niinomi, T. Akahori, J. Takeda and H. Toda: Mater. Sci. Eng., C25(2005), 363.

( 9 ) T. Saito, T. Furuta, J. H. Hwang, S. Kuramoto, K. Nishino, N. Suzuki, R. Chen, A. Yamada, K. Ito, Y. Seno, T. Nonaka, H. Ikehata, N. Nagasako, C. Iwamoto, Y. Ikuhara and T. Sakuma: Science, 300(2003), 464-467.

(10) H. Matsumoto, S. Watanabe and S. Hanada: Mater. Trans. 46 (2005), 1070-1078.

（11）舟久保熙康 編：形状記憶合金，産業図書，（1984）, 25, 34.

(12) H. Matsumoto, S. Watanabe and S. Hanada: Mate. Sci. Eng., A448 (2007), 39-48.

(13) H. Matsumoto, A. Chiba and S. Hanada: Mater. Sci. Eng., A486 (2008), 503-510.

(14) C. Leyens, M. Peter (Eds.): Titanium and Titanium Alloys Fundamentals and Applications, Wiley-VCH GmbH \& Co. $\mathrm{KGaA}$, (2003), 20-21.

(15) E. Schmid and W. Boas: Plasticity of Crystals, (1950), 21.

（16）松本洋明, 千葉晶彦, 源島文彦, 花田修治：塑性と加工, 50 (2009), 249-255.

(17) J. Sato, T. Omori, K. Oikawa, I. Ohnuma, R. Kainuma and K. Ishida: Science, $\mathbf{3 1 2}$ (2006), 90.

(18) A. Suzuki, G. C. DeNolf and T. M. Pollock: Scripta Materialia, 56 (2007), 385-388.

(19) Y. Gu, H. Harada, C. Cui, D. Ping, A. Sato and J. Fujioka: Scr. Mater., 55(2006), 815-818.

(20) A. Chiba and X. G. Li: Phil. Mag. A., 79(1999), 1533-1554.

(21) A. Chiba and M. S. Kim: Mater. Trans., 42 (2001), 2112-2117.

（22）只野智史，松本洋明，千葉晶彦，今野豊彦：第142回日本金属 学会講演概要, (2008), 217.

(23) 千葉晶彦：まてりあ，46(2007), 9-12.

(24) S. H. Lee, N. Nomura and A. Chiba: Mater. Trans., 49(2008), 260-264.

（25）山中謙太，森真奈美，黒須信吾，松本洋明，千葉晶彦：第143 回日本金属学会講演概要, (2008), 526 .

(26) Y. V. R. K. Prasad and T. Seshacharyulu: Int. Mater. Rev., 43(1998), 243-258.

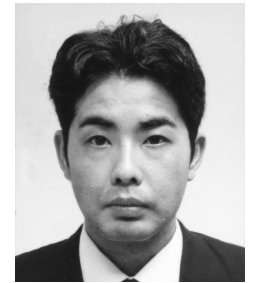

松本洋明

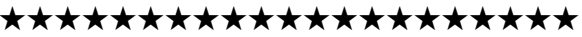
2001年 東北大学材料加工プロセス学専攻博士前期課 程修了

2001年 三井金属鉱業株式会社

2003年 東北大学金属材料研究所 助手

2006年 東北大学材料システム工学専攻＼cjkstart博士後期課 程修了

2007年 3 月 現職

専門分野 : 材料加工プロセス学, 金属組織学, 材料強 度学

○非鉄材料を中心とした各種加工プロセスを駆使した 組織制御と高機能化技術の研究開発に従事. 